\title{
Rereading The Empire Strikes Back
}

\author{
Gargi Bhattacharyya
}

When I was much younger - in education but without much sense that intellectual life in Britain might also include people who looked like me and shared my concerns this volume represented a rich source of inspiration and fantasy futures. Here I offer a version of my own teenage diaries and argue for the continuing importance of this work and the approach to intellectual endeavour that it represents.

\section{Thatcherism as an ordeal that sought to limit intellectual and political ambition}

Thatcherism had remade the political terrain drastically - riding the widespread sense of crisis in order to introduce the particular combination of laissez-faire economics, authoritarian social policy and popular nationalism that came to set the terms for mainstream politics for years to come. Unpacking the enormity of this onslaught has become the formative project that defines British cultural studies for much of the world. The Empire Strikes Back forms an important component of this larger project (famously represented by the groundbreaking analysis of Thatcherism, The Hard Road to Renewal) - yet also makes a case for placing discussion of the politics of race at the heart of social analysis. This is a work that seeks to respond to the urgent questions at hand - but also to reframe our longer-term understanding. As the authors say, and despite the 'contemporary', this is an attempt to write a history of the moment and through this to transform our approach to thinking about social change.

The 1980s in Britain felt bleak - to my teenage self, already well-schooled in the art of being invisible or running away in the face of calls to 'go home', the world of authority seemed uniformly and aggressively racist. Although (with some support from friendly schoolteachers) I was becoming more familiar with histories of US antiracist struggle and their accompanying traditions of black intellectual life, for me a British equivalent existed only in my fantasy life.

Into this whirlpool of teenage hope and expectation, The Empire Strikes Back felt like a confirmation that, somewhere out there, there was a world to which I could belong. Frankly, I have been on the search for it ever since.

\section{$\underline{\text { Political confidence }}$}

On re-reading, there is an appealing datedness about the register (replete with references to 'correct' analyses and positions). Although not obviously aligned to any particular political grouping (to my knowledge, the contributors to this volume are not among those most central to the project to rebuild an alternative political consciousness through the publication Marxism Today), there are repeated assertions that this publication is also a political intervention.

The volume is framed as an account of the crisis - arguably the last cataclysmic moment of global economic crisis to reshape the global economy until the speculation-fuelled disaster-fest of our time. In fact, and despite my strong attraction to this idea, the volume contains little examination of the economic crises of the time. Instead, this is an account of the manner in which economic and political crises 
become the occasion for an extended machinery of state racism. There is an audacity to the claim - this will to place race at the heart of the debate and as a necessary component of any serious understanding of our times. This seems to have been lost now, once again, discussion of the politics of race has become a specialist arena of little interest to those outside the clan. Against this, the opening of The Empire Strikes Back asserts the necessity of understanding the interconnections between racism and the wider reshaping of state activity and popular politics,

'The central theme of this book is that the construction of an authoritarian state in Britain is fundamentally intertwined with the elaboration of popular racism in the 1970s.' (8)

In a reminder of earlier battles in the field, the authors go on to specify their understanding of that fraught issue, relative autonomy.

'We see race as a means through which other relations are secured or experienced, this does not mean that we view it as operating merely as a mechanism to express essentially non-racial contradictions and struggles in racial terms. These expressive aspects must be recognised but race must also be approached in its autonomous effectivity.' (9)

The volume is as much an attempt to grasp the implications of the shift away from a confident Keynesianism as it is a comment on the state of 'race relations' - but it is also an argument that the heightened politicisation of the concept of race is an important aspect of this shift in state activity. The escalation and amplification of racist agitation - in government rhetoric and accompanying practices, in popular media, in the ruminations of academic work - shows the role of selective demonisation and marginalisation in facilitating this attack on previous agreements around entitlement, security and the role of the state. Whereas when I first read this work, my focus was on the need to develop an analysis of the pervasive influence of racism on everyday life in Britain, on my recent re-reading I was struck by the push to historicise the crisis and by the lessons for our own moment.

The account of the multi-faceted political crisis that provides the context for the particular revamping of state and popular racisms examined in this volume is remarkably familiar. Economic collapse, an attack on living standards, distrust of political representatives leading to a lack of political engagement, rapid restructuring of the state and a resurgence of racist political agitation (18) - it is hard not to note the parallels with our own moment, also undergoing a rapid remaking of state activity in the face of economic crises and a loss of political credibility. However, whereas in 1981 the authors feel confident that the response to these overlapping crises is played out through 'A racializationn of state policies in all areas of social life' (17), critics of our current crisis are less likely to make a connection with the politics of race.

Instead, the consensus appears to be that it is the issue of migration that has seeped into all state policies, with a parallel and repeated assertion that debates about immigration are nothing to do with race.

The authors of The Empire Strikes Back reveal sheepishly that they have bitten off more than they can chew - including, in the manner of that time, careful acknowledgements of the important issues that had not been included sufficiently 
(Asian experience, black women's struggles, the experience of work and black workers in the labour movement). Yet what is more surprising is how much is included: an outline of the rush to racialised/racist politics in the face of economic crisis; a detailed discussion of the racist assumptions informing mainstream writing in policy-orientated sociology of that time; chapters on policing, schooling, black feminism and Asian women's struggles in and beyond the workplace, each of which stretches to reflect and engage with activist preoccupations. Inevitably, the end product is crowded but suggestive - both a manifesto and an invitation to join the project of what I still think of as black cultural studies.

Sadly, some of my favourite elements of the whole endeavour seem less available now. Recent years have seen few attempts to bring together an analysis of the lived experiences of racism and shared political interests of Asian, African and Caribbean communities. Equally telling for our time, there is little sign of the emergence of any shared intellectual and political project to bring together so-called migrants and socalled settled black communities. The slightly self-conscious but concertedly cooperative approach of The Empire Strikes Back shows an approach to scholarship that imagines such work as an integral component of coalition-building, and coalitionbuilding as the only route to racial justice.

The collective approach to learning and writing that emerges from this strong sense of participating in a movement for change has also been all but eradicated from academic life. The marketisation and accompanying bureaucratisation of almost all aspects of academic life, with demands that all activity be shown to lead to a quantifiable outcome, with clear attribution of responsibility for the purposes of increasingly onerous and divisive performance indicators, all militates against cooperative working, most of all in the competitive area of publication. It is hard to imagine a role for local activists in the processes of producing academic writing today, or many concerted attempts to develop collective writing over a sustained period of time.

\section{Bringing together feminism and class analysis with politics of race}

Although the authors apologise for a failure to adequately address issues of gender, my own impression was of a collection that placed black feminism at the heart of the most pressing political challenges of the time. Importantly to me, this was an approach where analysis of the experiences of racism and sexism was essential to any understanding of workplace struggles, where feminism was central to the struggle but white feminism was critiqued for an ignorance and sometimes an antipathy to the concerns of black women, and where ideologies of idealised families and parallel imaginings of gender and sexuality were identified as part of the repertoire of racist logic that informed state racisms. Whatever the internal tensions of the group and the failures of the larger left, I read this book as a confirmation that women mattered and that there could be no effective struggle for change without our participation. In common with many other young women, my everyday experience at the time did not always suggest that women were valued in the community, in the struggle or anywhere else. Just having access to writing that confirmed that serious people thought differently - and that black British women wrote serious things - felt very important and sustaining. 
Perhaps the most marked historical distance is in the assumption that the interlocutor for these debates about race, class and gender is steeped in the internal battles of the political left. Instead of seeking to influence those in power - who have declared their quite different interests - this is a work that addresses itself to those who wish to participate in progressive alliances yet fail to engage with the particularities of black politics. As Paul Gilroy summarises in the final chapter,

'It is about class struggle. Our premise is therefore the problem of relating 'race' to class, not for sociological theory, but for socialist politics.' (275)

Although the tone is somewhat fractious - and highly critical of colleagues in the field - the project remains the task of formulating knowledge that can rally resistance. In our times of market-orientated understandings of the impact of research, these arguments about the attitude to knowledge that might best inform an alternative politics seem long ago. With the benefit of hindsight, perhaps the focus on the 'correct' position to adopt and the extensiveness of the failings of others has not been the most productive approach to building co-operation and a broader alliance for change. In 2013, it feels to me that there are all too few potential comrades and scholarly disagreements are less important than a sense that we are all seeking justice, albeit via differing paths.

The critique of those who have embraced an account of black politics as a form of popular movement is framed - acutely in my view - in terms of what such an account is given to represent.

'Race has become important at last, not because of black suffering, but because it can be used to demonstrate the distance Marxists have travelled from economism. Unfortunately, the analysts of 'race' in this influential tendency have expounded the popular and democratic qualities of the struggle for black liberation to the point where its class character has escaped them.' (276)

Discussion of 'race', therefore, becomes a pretext or signal of some other dispute about the nature of class or the character of the struggle - and through this, is regarded as quite divorced from lived class relations. This is the other side of the dispute about relative autonomy. On the one hand, issues of race are argued to be more than epiphenomena of economic relations and, therefore, demand specific forms of struggle that cannot be subsumed under (or led by) workerist revolutionary groupings. On the other, black struggles are seen to embody lived class relations and to suggest points of productive tension that could renew the wider movement. Before readers snort with derision, I should confess that no-one has rehearsed this argument in my presence for a long time - and also that I regret the passing of the sense that this is an important thing to understand. Nowadays, accounts of class identities that come my way tend to be focused on cultural articulations of one sort or another, including the important issue of how class hierarchies are internalised and perpetuated while the category of class becomes invisible and unspeakable. Much of this more recent work has a focus, either explicitly or inadvertently, on the white working class - and I understand why this has been regarded as a necessary and urgent response to the continuing dispossession of working-class communities. However, there has been a failure to remember the classed experiences of communities of colour or to link struggles within those communities to accounts of class relations. 
In our own time of crisis, with its own challenges of changing state practices and renewed authoritarianism, also coupled with economic breakdown and an overwhelming political vacuum, there seem to have been few attempts by scholars to mount a collective analysis and political alternative. The Aftermath project brought together by Manuel Castells is an honourable exception - and this grouping does not seem attentive to the place of racism in the resurrection of authoritarian tendencies. Perhaps there is a need for scholars of racism to come together to consider recent challenges? I hope remembering the context of this influential work will encourage us all to think again about what scholars can do to illuminate the crises of our own time.

All quotations taken from 'The Empire Strikes Back', London, Hutchinson (sorry need to check issue that I was using when my internet access is easier) 